\title{
The Perception of Micro-Entrepreneurs towards the Adoption of an Islamic Equity-Based Financing: Evidence from Malaysia
}

Siti Hajar Binti Mohd Abd Khar, Muhammad Pisol bin Mohd Mat Isa, Maran Marimuthu, Amin Jan (Corresponding Author)

Department of Management \& Humanities (Social Science)

Universiti Teknologi PETRONAS Perak, Malaysia

E-mail: Amin_jan_khan@yahoo.com

Received: April 19, 2019 Accepted: October 2, 2019 Published: October 8, 2019

doi:10.5296/bms.v10i2.15586 URL: https://doi.org/10.5296/bms.v10i2.15586

\begin{abstract}
This paper aims to explore the perception of micro-entrepreneurs towards the adoption of equity-based financing models in Malaysia. The investigation has covered the following characteristics of equity-based financing such as fairness, partnership, risk sharing, business size, and MFI. The current micro-financial products in Malaysia are focusing more on debt-based financing, which is holistically increasing the financial risk level of entrepreneurs in the case of defaults. There is a dire need to identify the relevancy and viability of equity-based financing in Malaysia, it will ultimately reduce the financial risks of entrepreneurs in case of default. The Islamic financial concept offers a solution to this problem, Musharakah and Mudarabah are among the other Islamic products that offer equity-based micro-financing to entrepreneurs. However, its practical implementation is still vague. In relation to this, the study adopts a cross-sectional study with a sample size of 700 micro-entrepreneurs from the state of Selangor Malaysia. The results of this study found that micro-entrepreneurs tend to register a positive perception of the characteristics of equity-based financing and risk-sharing score as the highest factor towards the adoption of the proposed equity-based PLS model in Malaysia.
\end{abstract}

Keywords: Islamic micro-financing, equity financing, Malaysian micro-entrepreneurs

\section{Introduction}

Microfinance is a part of the financial sector which is recognized as a pivotal tool for 
alleviating poverty (Abduh and Azmi Omar, 2012). Microfinance is defined as a program that helps poor people in the community. The initiative is to empower them in generating an income that finally allows them to take care of their families. The poverty and income inequalities are the serious issues that are being addressed worldwide. The World Bank has taken the righteous initiative of recognizing micro-financing programs throughout the world. It proved successful in eradicating poverty in many countries (Abdul, 2010). Micro-financing is not only eradicating poverty, but it also encourages the poor to have entrepreneurial abilities which help them in generating the income simultaneously functioning as the tool of poverty reduction. It means that micro-financing is also functioning as a tool for the poor to become micro-entrepreneur (MFE). Wajdi Dusuki (2008), argued that micro-financing has resulted the priority in pursuing of policy to finance small and medium enterprises that are normally not bankable or do not have access to get financing in mainstream financial institutions and markets. The outstanding example of successful MFIs (MFI) is Grameen bank initiated by Muhammad Yunus. He was granted the Nobel Peace Prize in 2006 based on his contribution to bringing micro-financing products at the world level (Wilson, 2007). The micro-financing model of Grameen Bank became a replica to most of the MFI in various countries around the world. This model is based on trust where there is no collateral asset required but instead using the group-based lending mechanism to mitigate the credit risk perceived (Abdul, 2010).

In Malaysia, Amanah Ikhtiar Malaysia AIM, based on Grameen's bank model acts performs as the biggest MFI. Besides AIM, there are several other institutions that provide micro-financing to the poor and MFE such Yayasan Usaha Maju YUM, Tabung Ekonomi Kumpulan Usaha Niaga TEKUN, Yayasan HIJRAH, and several commercial and development banks. Equity financing best known as Profit and Loss Sharing PLS are the products that are encouraged by majority of the Muslim scholars. It is because these products promote justice and equality among the financial provider and the clients. The products of equity financing are Mudarabah, Musharakah and Musharakah Mutanaqisah, which is required participation of MFI especially in dealing with the business by sharing its knowledge, expertise and business risk in the event of default, the beauty of this product where both parties will discuss the share capital, the share risk and the share of profit generated from the business, this mutual participation and partnership will likely to enhance productivity and successfulness of business. Bait al-Mal wa Tamwil BMT is the example of non-governmental institutions which promote equity-based financing in Indonesia, they have proved to be a successful institution in carrying the mission and well accepted among MFE's community. MFIs shall treat these products with high scrutiny (Widiyanto and Abdul 2010). Since the equity-based financing will involve default risk to both parties, where the possibility of default may likely to happen therefore, scholars (Widiyanto and Abdul 2010) have investigated the procedures and processes by which the criteria has emerged as the contributing factors to the success's implementation of equity-based products, the study include among them the financing products, capital control, selection process, business control, incentive system of good repayment and the relationship between MFE and funder. 
In the context of equity financing, selection process and business control are important in ensuring the delivery of the products to the clients. Smolo and Abdul, (2010) suggested that selection process and business control is important to ensure both parties effectively contribute to the success of financing, Smolo, and Abdul, (2010) also stressed that selection process must be done as early as establishment of connection between the MFE and MFI, the process of evaluation should cover the individual personality, skill, capacity, business information, and business control. This will enable both parties to know the progress of the business in alleviating the possible risk of default or misfortune in financing. The PLS model is yet to be introduced to the microfinance industry in Malaysia. The majority products offered by Malaysian MFIs are debt-related financing which normally applied under the concept of Qardh-ul-Hasan and Commodity Murabahah financing. Likewise, the Indonesian practice, the MFIs are progressively providing both concepts (equity and debt financing) to micro-entrepreneurs. Whereas MFIs in Malaysia are yet to introduce the concept, hence this study will investigate the perception and acceptance of Malaysian MFE on the characteristics of equity financing model (partnership, fairness, and risk-sharing) in microfinance industry particularly the concept of PLS in Malaysia.

\section{Literature Review}

The performance of Islamic banking in Malaysia is studied from different angles. The notable work in the field of Islamic banking in Malaysia is done by (Jan and Marimuthu, 2015a, Jan and Marimuthu, 2015c, Jan and Marimuthu, 2015b, Jan and Marimuthu, 2016, Jan and Marimuthu, 2019, Jan et al., 2019a, Jan et al., 2018, Jan et al., 2019b). Basically, Islamic MFIs are established to help the poor and micro-entrepreneurs to generate an income which finally allowing them to take care of their families (Microcredit Summit, 2004). Islamic financing concept has various product models that could be implemented by Islamic MFIs in serving their clients. Microcredit institutions are only offering products on credit financing while neglecting the equity product to poor borrowers (Pramanik et al., 2015). This actually has caused mismatch between the demand for the financing and supply of the financial services in microfinance industry. Despite the strong development of Islamic financial system in Malaysia, the MFIs such as TEKUN, YUM and AIM still much rely on the debt-based only. AIM as the largest MFIs in Malaysia also focusses only on Qardh-ul-Hasan (benevolent loan) and Commodity Murabahah (Cost plus mark-up). Pramanik et al. (2015), revealed that in Malaysia, Commodity Murabahah seems to be the most dominant mode of financing. Due to this situation, the MFIs in Malaysia are left with no choice to choose the type of financing which is more suitable for their businesses. This development is unlike to counterpart of Indonesian MFI, where the product offering is diversified into both debt and equity, and both received an equal chance to progress. Shahinpoor (2009), discussed the application of Islamic microfinance in the Islamic banking sector with the suggested product model such as Qardh-ul-Hasan, Murabahah Sale (cost plus mark-up sale contract), Ijarah (Leasing contract), Musharakah and Mudarabah (profit and loss sharing), and Takaful (mutual insurance) (Nimrah, Michael, \& Xavier, 2008). To improve marketability of the microfinance products, other products such as Bay' al-Salam (pre-paid purchase), Bay' al-Istisna' (progressive 
financing), Ijarah Wa Iqtina (lease to purchase), Musharakah Mutanaqisah (diminishing partnership) should also be considered.

PLS is a unique concept which only identified in Islamic teaching, the concept features the partnership element of sharing of risk and returns, this concept actually breaking the norm of the conventional financial system is normally debt-based where the loaner always at the secured position but will receive a return in any circumstances. The general term of the contract is about to share profit as well as to bear the loss. The concept is less explored in microfinance sector, meanwhile it is tremendously applied in Islamic banking sector. The idea of profit and loss sharing in MFI is to drive away from the normal practice of risk-bearing where the financing institution would transfer all financial risk to MFE, this concept will guarantee MFI with the return without any risk-bearing (Chowdhury, 2013).

PLS concept is a partnership agreement between two parties (MFI and MFE) where the profit and loss are distributed based on a contribution of capital share and effort by the partners (Ahmad and Ahmad, 2008). PLS model will require MFIs to continue to work together with MFE as a partner, business advisor as well as risk bearer, therefore this concept will ensure that MFI is not merely administering loans but participating in business. In addition to that, PLS is the most effective concept and mechanism to assist the less fortunate community due to the group does not only require a business capital but advice and guidance in dealing with the complexity of today's business activity. According to Abdul (2010) PLS model is more efficient in terms of business facilitation and supervision toward the success of fund management, especially the needy and poor community. The function of MFI is to provide capital to the entrepreneur, where it also needs to contribute the managerial expertise into the projects, MFI may need to participate in the business in order to ensure the profitability of the entity. The profit ratio is predetermined by mutual consent of both parties. In the event of loss both parties will bear the cost and take full responsibility (Abdul, 2010).

\section{Methodology}

\subsection{Sample and Population}

The population of this study is the micro-entrepreneurs who have already subscribed to the micro-financing products in Selangor, Malaysia. The sampling frame for this population is the micro-entrepreneurs that were residing in Selangor. The state of Selangor was chosen for this study because of the high number of entrepreneurs that were involved in this industry. The total number of registered SMEs in Selangor was 125,904, and out of that, 74.4 percent or 93,673 were microenterprises as indicated by Department of Statistics of Malaysia. The study distributed 700 questionnaires and has managed to collect 611 responses.

\subsection{Data Collection}

The data were collected is self-administrated which was distributed to registered SMEs in Selangor, the distribution was based on three zones that are, central, northern and the southern zone, each zone consisted of seven branches. Using stratified sampling technique 


\section{Al Macrothink}

data were collected from all three zones respectively.

\subsection{Development of the Questionnaire}

The questionnaire was specially developed to suit the proposed conceptual framework. The instrument was adapted from Widiyanto and Abdul (Widiyanto \& Abdul, 2010), Norma (2012), Norma and Jarita (2010) Fatimah Salwa et al (2013), and Salwana Hassan et al (2013). The unit of analysis is individuals. The sampling frame was the list micro-entrepreneurs Respondents mainly as outlined by AIM (Amanah Ikhtiar Malaysia) through which a sample size of 700 was drawn. It was a cross-sectional study coupled with FGDs to strengthen the primary data received through questionnaire survey. The questionnaire was divided into 4 sections. The first section was about the micro-entrepreneurs' demographic and business information. The second section was about the characteristics of Islamic MFIss, characteristics of the PLS financing, and the adoption of PLS model. The third section comprised the characteristics of PLS products which were categorized as partnership, fairness or fair contract, and risk-sharing. Finally, the fourth section focused on the acceptance or the perception of the respondents toward the adoption of discussed models in Malaysia. These sections used 5 points of Likert scale from strongly disagree to strongly agree. The proposed conceptual framework is presented in figure 1.

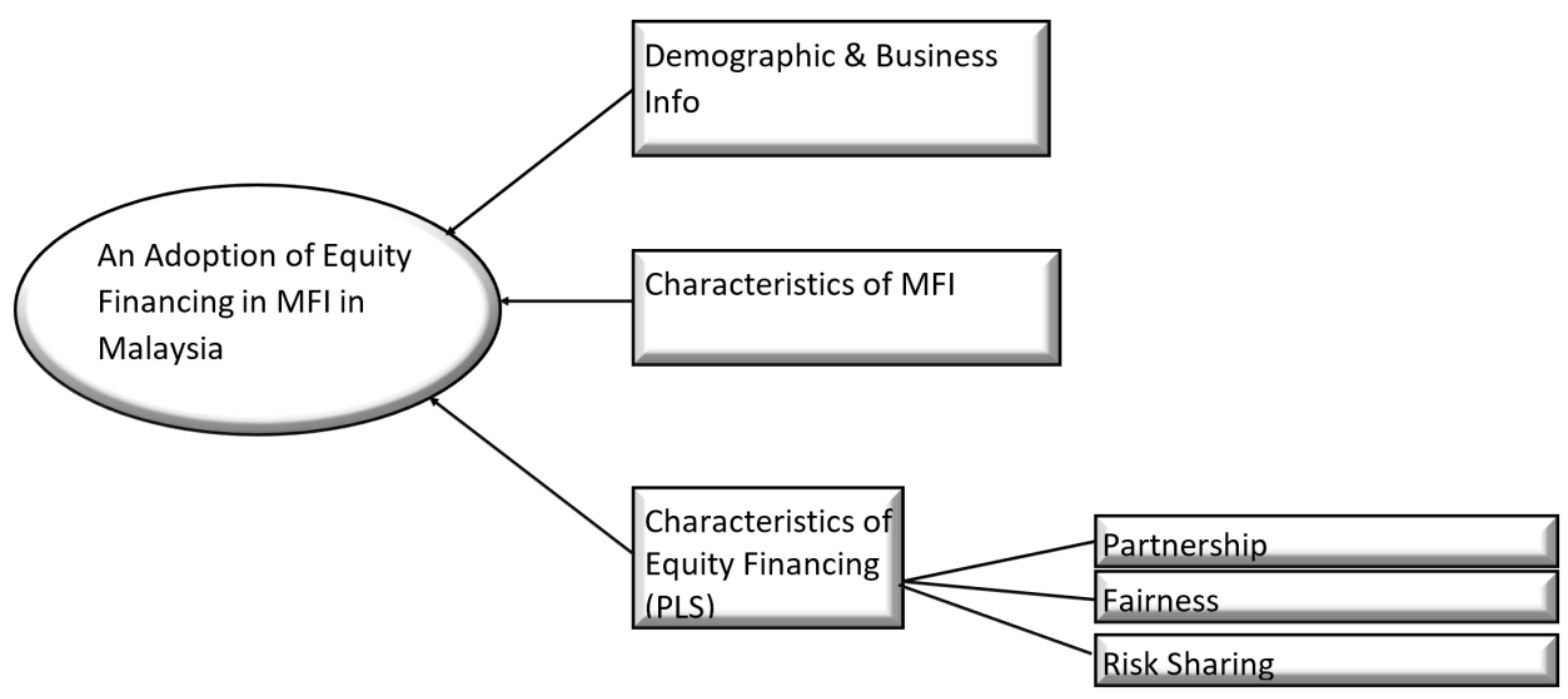

Figure 1. Adoption of Equity Financing in the Islamic MFIs in Malaysia 


\section{Result and Discussions}

\subsection{Correlation Matrix}

\begin{tabular}{llllll}
\hline Variables & Adoption & MFI & Risk Sharing & Partnership Fair Contract \\
\hline Adoption & 1 & & & & \\
MFI & $.517 * * *$ & 1 & & & \\
Risk Sharing & $.587 * * *$ & $.527 * * *$ & 1 & & \\
Partnership & $.593 * * *$ & $.598 * * *$ & $.726 * * *$ & 1 & 1 \\
Fair Contract & $.564 * * *$ & $.529 * * *$ & $.670 * * *$ & $.769 * * *$ & 1 \\
\hline
\end{tabular}

*means $10 \%$ significance level, **means $5 \%$ significance level, ***means $1 \%$ significance

Table 1 shows the results of the correlation matrix. It shows the relationships between the risks sharing, partnership, fair contract, characteristics of MFI and business size against the adoption of PLS. The relationships of these variables were investigated using Pearson product-moment correlation coefficient. It was found that there was a strong positive correlation between two variables, $\mathrm{r}=0.587, \mathrm{n}=611, \mathrm{p}<0.005$, with high levels of Risk Sharing values associated with high levels of the adoption of PLS contract. While for Partnership, a strong positive relationship also indicated against the adoption of PLS contract where $r=0.593, n=611, p<0.005$. Then, the same as the fair contract, it also shows a strong positive relationship toward the adoption of PLS where $r=0.564, n=611, p<0.005$, with high levels of Fair Contract values associated with high levels of the adoption of PLS contract. Furthermore, it was found that the characteristic of MFI also has positive influence on the adoption of PLS where $\mathrm{r}=0.517, \mathrm{n}=611, \mathrm{p}<0.005$. These variables such as (risk-sharing, fair contract, and partnership) are the main characteristics of Islamic equity financing, these elements are customer-oriented and placing right to entrepreneurs' equal right especially when the business experience decline. This result is consistent with other findings of PLS research. Akhtar (1997) has conferred in his study on the role of partnership in providing financing to the micro-entrepreneurs in order to reduce poverty. In the research, he has discovered that participatory financing such Mudarabah and Murabahah were successful in catering the PLS financing to the micro-entrepreneurs. The element of partnership in the study helps the micro-entrepreneurs to perform better in the business and result to an upgrade of standard of living. On the independent variable (characteristics of MFI), the strong correlation is due to the perceived belief of the MFI will provide efficient service, flexibility in payment of arrears, speedy evaluation and approval process, Shariah-compliant and required a minimal process of application.

Meanwhile, Business Size was not a significant variable towards the adoption of PLS contract, this is due to less concern on this item, where Micro-Entrepreneurs have a great concern on the Shariah-compliant issue, thus the other set of independent variables (Risk 
Sharing, Partnership, and Fair Contract) and control variable of characteristics of MFI have offered great values to the Micro entrepreneurs.

Table 1 shows the correlation results of the variables used. It shows that all the variables used in this study have their p-values to be significant at 0.01 percent. It implies that all these variables are contributing positively towards the adoption of PLS in Malaysia. This result is consistent with the previous study which has a variety of products including Mudarabah, Musharakah and Musharakah Mutanaqisah are able to improve the micro-entrepreneurs' business performance. Widiyanto (2007) has discussed in his research that micro-financing that has variety of features is effective for the development of micro-entrepreneurs. In his finding, equity micro-financing of BMT are highly consumed by the micro-entrepreneurs. The uniqueness of the equity-based concept is requesting the MFI to bear some financial risk if, in case of the business default, this implantation would call the MFI to take extra caution and provide some business advice which in away can develop a business skill to the microfinance entrepreneurs. For the question "I believe financing that shares the profit and loss between the participant and the MFIs is the most suitable financing for micro-entrepreneurs". The score is $60 \%$ and $16.5 \%$ of the respondents that agree and strongly agree with the above statements. This is likely that the respondents perceive the goodness in characteristics of the contract that shares the profit and loss. It is undeniable that sharing profit and loss has promoted justice among the parties involved. Furthermore, the respondents have experienced through directly financed by the MFI. By looking at the data, majority of the respondent have positive perceptions towards the MFI. Due to that fact, it is likely that they found that MFI is the reliable institutions that could provide the proposed financing. However, the Business Size difference is not a significant factor might be because the range of the business size still falls within the Micro sector.

Table 2. Regression Results

\begin{tabular}{|c|c|c|c|c|c|}
\hline \multirow{2}{*}{$\begin{array}{l}\text { Dependent Variable } \\
\text { (Adoption of PLS) }\end{array}$} & \multicolumn{2}{|c|}{ Unstandardized Coefficients } & \multirow{2}{*}{$\begin{array}{l}\text { Standardized Coefficients } \\
\text { Beta }\end{array}$} & \multirow{2}{*}{$\mathrm{t}$} & \multirow{2}{*}{ Sig. } \\
\hline & Beta & Std. Error & & & \\
\hline MFI & $0.233 * * *$ & .045 & .199 & 5.151 & .000 \\
\hline Business Size (number of employees) & $0.040 * *$ & .021 & .059 & 1.933 & .054 \\
\hline Risk Sharing & $0.335 * * *$ & .06 & .249 & 5.387 & .000 \\
\hline Partnership & $0.178 * * *$ & .057 & .173 & 3.135 & .002 \\
\hline Fair Contract & $0.150 * * *$ & .048 & .153 & 3.095 & .002 \\
\hline R-squared= 44 & & & & & \\
\hline
\end{tabular}

*means $10 \%$ significance level, $* *$ means $5 \%$ significance level, $* * *$ means $1 \%$ significance

Table 2 shows the results of the hierarchical regression. In the Model Summary, there are 2 blocks of variables where the first block consists of MFI characteristics and Business size, 
while the second block consists of MFI characteristics, Business Size, Partnership, Risk Sharing, and Fair contract. R-squared was recorded with 44 percent. In order to know how much of this overall variance is explained by the independent variables (Partnership, Risk Sharing \& Fair Contract). It is stated that the Partnership, Risk Sharing \& Fair Contract explain 16.9 percent $(0.169 \times 100)$ of the variance in the adoption of profit and loss sharing when the effect of MFI characteristics and Business Size are statistically controlled.

Then, it is also necessary to identify which of the variables contribute significantly to the equation. In order to explore that, we need to check the Coefficient Table 1. Looking at the Sig. column, all the variables make a statistically significant contribution (less than 0.05) except for the control variable of Business Size. In order of importance, Risk Sharing made the most unique contribution (beta $=0.249$ ) followed by control variable of MFI characteristics $($ beta $=0.199)$, Partnership $($ beta $=0.173)$ and Fair Contract (beta $=0.153)$.

The result shows that Risk Sharing play as the most crucial variable that influences the adoption of PLS in Malaysia. This seems that the value of Risk Sharing is most needed in the financing of the Micro entrepreneurs. It is might be because current financing charge management fees (Qardh-ul-Hassan) and fixed profit rate (Murabahah) to the financing are burdening them. It is understandable that the profit rate charged upon them is burdening because they must pay for it even though they faced losses in their businesses. This Risk Sharing will be decided at the beginning of the contract when they agree to the profit and loss ratio between the micro-entrepreneur and MFI. Then they would appreciate if they only have to pay up if there are profits gained from the businesses. Furthermore, they also could share and lessen the burden when they faced losses in the business. For the question 'I am sure financing that shares the profit and loss between the participant and the MFIs are far better than the loan that charge management fees.'

Then the characteristic of MFI is the second-highest in influencing the adoption of the PLS in Malaysia. This is likely because they deal with MFI more than other financial institutions makes them trust MFI greatly. The success rate of adopting other micro-financing products into the MFI would be high. This is because they have experiences in engaging with the lower-income earner, the micro-entrepreneur, and the poor. Then this would raise the opportunity that they could manage to introduce new Equity Products to their current target group by considering their current perspective towards them.

\section{Conclusion}

This paper is motivated by an effort to fill the gap by offering an Islamic equity-based financial model or best known as PLS to micro-entrepreneurs in Malaysia. It is concluded that the characteristics of PLS contract which covers fairness, partnership, risk sharing, business size, and MFIs are positively affecting the adoption of the proposed Islamic equity-based PLS financial model. In line with the regression results as shown in Table 2, the variable of risk sharing is believed to be the highest factor towards adoption of the proposed equity-based PLS model. It is anticipated that the adoption of the subjected Islamic 
equity-based financing model by the MFIs in Malaysia will bring positive results in the micro-financing sector of Malaysia. It further alludes that the successful micro-financing sector in Malaysia will help its GDP growth rate, as a result, it will help Malaysia in achieving its $11^{\text {th }}$ developmental plan (2016-2020), and the post 20-20 developmental plans.

\section{Acknowledgment}

This research is funded by the Fundamental Research Grant Scheme (FRGS) Ministry of Education Malaysia.

\section{References}

A.H.Fatimah-Salwa, A., Mohamad-Azahari, B., \& Joni-Tamkin. (2013). Success Factors of Successful Microcredit Entrepreneurs: Empirical Evidence from Malaysia. International Journal of Business and Social Science, 4(5), 153-159.

Abduh, M., \& Azmi Omar, M. (2012). Islamic banking and economic growth: the Indonesian experience. International Journal of Islamic and Middle Eastern Finance and Management, $5,35-47$.

Abdul, R. A. R. (2010). Islamic microfinance: an ethical alternative to poverty alleviation. Humanomics, 26(4), 284-295. https://doi.org/10.1108/08288661011090884

Ahmad, A. U. F., \& Ahmad, A. R. (2008). Islamic microfinance: A case study of Australia. Journal of Islamic Economics, Banking and Finance, 4, 59-80.

Akhtar, M. R. (1997). Partnership financing of microenterprises. International Journal of Social Economics, 24(12), 1470-1487. https://doi.org/10.1108/03068299710193930

Asyraf, W. D. (2008). Banking for the poor: the role of Islamic banking in microfinance initiatives. Humanomics, 24(1), 49-66. https://doi.org/10.1108/08288660810851469

Chowdhury, N. (2013). Mushārakah and Mudārabah instuments: Theory development to assess their characteristics, 10(2).

Hassan, S., Abdul Rahman, R., Abu Bakar, N., Mohd, R., \& Muhammad, A. D. (2013). Designing Islamic microfinance products for Islamic banks in Malaysia. Middle-East Journal of Scientific Research, 17(3). https://doi.org/10.5829/idosi.mejsr.2013.17.03.12160.

Jan, A., \& Marimuthu, M. (2015a). Altman Model and Bankruptcy Profile of Islamic Banking Industry: A Comparative Analysis on Financial Performance. International Journal of Business and Management, 10, 110.

Jan, A., \& Marimuthu, M. (2015b). Bankruptcy and sustainability: A conceptual review on islamic banking industry. Global Business and Management Research, 7, 109.

Jan, A., \& Marimuthu, M. (2015c). Sustainability Profile of Islamic Banking Industry: Evidence from World Top Five Islamic Banking Countries. International Journal of Economics and Finance, 7, 125. 
Jan, A., \& marimuthU, M. (2016). Bankruptcy Profile of Foreign vs. Domestic Islamic Banks of Malaysia: A Post Crisis Period Analysis. International Journal of Economics and Financial Issues, 6.

Jan, A., Marimuthu, M., bin Mohd, M. P., \& Isa, M. (2019). The nexus of sustainability practices and financial performance: From the perspective of Islamic banking. Journal of Cleaner Production, 228, 703-717.

Jan, A., marimuthU, M., Bin Mohd, M. P., Isa, M., \& Shad, M. K. (2019a). Bankruptcy Forecasting and Economic Sustainability Profile of the Market Leading Islamic Banking Countries. International Journal of Asian Business and Information Management (IJABIM), 10, 73-90.

Jan, A., marimuthu, M., Pisol, M., Isa, M., \& Albinsson, P. A. (2018). Sustainability Practices and Banks Financial Performance: A Conceptual Review from the Islamic Banking Industry in Malaysia. International Journal of Business and Management, 13.

Jan, A., Marimuthu, M., Shad, M. K., Ur-Rehman, H., Zahid, M., \& Jan, A. A. (2019b). Bankruptcy profile of the Islamic and conventional banks in Malaysia: a post-crisis period analysis. Economic Change and Restructuring, 52, 67-87.

Microcredit Summit. (2004). State of Microcredit Campaign Summit Report.

Nimrah, K., Michael, T., \& Xavier, R. (2008). Islamic Microfinance : An Emerging Market Niche. Focus Notes, 49(August), 1-16.

Norma, M. S. (2012). Microfinance and Prospect for Islamic Microfinance Products: The Case of Amanah Ikhtiar Malaysia. Advances in Asian Social Science, 1(1), 27-33. Retrieved from http://worldsciencepublisher.org/journals/index.php/AASS/article/view/51/64

Norma, M. S., \& Jarita, D. (2010). Determinants of Economic Performance of Micro-Credit Clients and Prospect of Islamic Microfinance in Malaysia. ISRA International Journal Of Islamic Finance.

Pramanik, A. H., Mustafa, O. M., Mohamed, A. H., Fouad, M. A., Aliyu, D. M., Nabil, D., \& Kenan, B. (2015). Integration of Waqf and Islamic Microfinance for Poverty Reduction.

Shahinpoor, N. (2009). The link between Islamic banking and microfinancing. International Journal of Social Economics, 36(10), 996-1007. https://doi.org/10.1108/03068290910984777

Smolo, E., \& Abdul, G. I. (2010). A theory and contractual framework of Islamic micro-financial institutions' operations. Journal of Financial Services Marketing, 15(4), 287-295. https://doi.org/10.1057/fsm.2010.24

Widiyanto, M. C. H. (2007). Effectiveness and Sustainability of Baitul Mal Wat Tamwil Financing in the Development of Micro-Enterprises in Central Java, Indonesia. Universiti Putra Malaysia. 
Widiyanto, M. C. H., \& Abdul, G. I. (2010). Improving the effectiveness of Islamic micro-financing Learning from BMT experience. Humanomics, 26(1), 65-75. https://doi.org/10.1108/08288661011025002

Wilson, R. (2007). Making development assistance sustainable through islamic microfinance. IIUM Journal of Economics and Management, 15(2), 197-217.

\section{Copyright}

Copyright for this article is retained by the author(s), with first publication rights granted to the journal.

This is an open-access article distributed under the terms and conditions of the Creative Commons Attribution license (http://creativecommons.org/licenses/by/4.0/). 